\title{
Use Of Natural Gas Become a Petrochemical with Zeolite Catalyst
}

\author{
S. Susilowati ${ }^{*}$, and Novel Karaman \\ Master of Environmental Science Study Program, University of Pembangunan Nasional "Veteran" East Java \\ Surabaya, Indonesia.
}

\begin{abstract}
Methane is a hydrocarbon compound that can be used for various purposes. Currently, methane is widely used as fuel, and continues to be developed as a synthetic gas material and petrochemical products that have added value, one of which is formaldehyde. This study aimed to study the partial catalytic oxidation reaction of methane to formaldehyde using $\mathrm{MoO}_{3} /$ zeolite as a catalyst. Reactant gas stream consisting of pure $\mathrm{O}_{2}$ and $\mathrm{CH}_{4}$ were contacted with a rate ratio of 1:20, put into Fixed Bed Reactor therein contained 30 grams of catalyst $\mathrm{MoO}_{3} /$ zeolite, and the pressure was maintained at $1 \mathrm{~atm}$. The temperature and flow rate of the incoming reactant gas were used as variables. The main product produced was formaldehyde, besides that there were also $\mathrm{CH}_{3} \mathrm{OH}, \mathrm{CO}, \mathrm{CO}_{2}, \mathrm{H}_{2} \mathrm{O}$. The results were analyzed using Gas Chromatography, so it was known that the converted methane was $5.18 \%$ and the volume fraction of formaldehyde formed was $1.46 \%$.
\end{abstract}

Keywords: Natural Gas, Zeolite Catalyst, Methane

\section{Introduction}

Zeolite is an acid catalyst that is interesting enough to be investigated and studied further for its performance in catalyzing hydrocarbon reactions. This is due to the nature of zeolite which is generally suitable as a catalyst or as a catalyst support. Therefore, zeolites can be used as filters, ion exchangers, absorbent materials and catalysts [1]. This suitability is due to the structure of the zeolite which generally provides effective site cavities for several chemical reactions, at high temperatures the catalyst activity is more effective, $\mathrm{H}$ zeolite has good activity stability [2].

In Indonesia, the availability of zeolites is in large enough deposits. However, its benefits are still not so widespread. Methane is a hydrocarbon that can be utilized for various needs. The main use of methane at this time is as a fuel, recently it has been continuously developed as a synthetic gas material and also other petrochemical products. In connection with very excessive and cheapness of methane encourage people to convert it into other products that have added value. Which now has done are converting vapor methane into syngas, converting the syngas into methanol and then converting methanol into chemicals which are more useful for example, methanol can be oxidized to formaldehyde through commercial catalytic processes. Formaldehyde is known as a raw material for manufacturers of insulation and adhesive materials. Formaldehyde industries generally use metal catalysts of $\mathrm{Fe}$ and $\mathrm{Mo}$, as the metal catalyst is more tolerant of contaminants so that widely applied in the industries [3].

The partial oxidation reaction of methane to formaldehyde was carried out by Spencer [4]. Through the experiments, Spencer reacted methane and oxygen gas with a molar ratio of 19: 1 to $6: 1$ at a pressure of $1 \mathrm{~atm}$. The gas was flowed through the $\mathrm{MoO}_{3} / \mathrm{SiO}_{2}$ catalyst at a temperature variable of $848^{\circ} \mathrm{K}$ to $923^{\circ} \mathrm{K}$ and a gas velocity (GHSV) of $2500-10000$ per hour. Results of Spencer's experimet showed that methane was converted around $0-5 \%$, while the selectivity of formaldehyde between $30-89 \%$. As well as known that mechanism of oxidation of methane into formaldehyde of the order of 1 to methane, the reaction equation as follows:

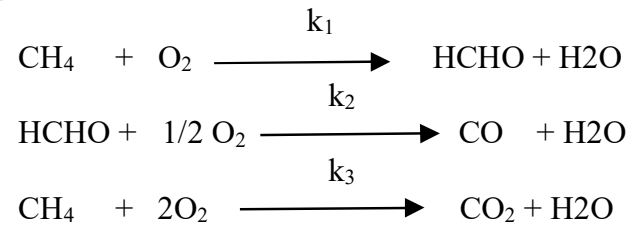

\footnotetext{
* Corresponding author : zuzisukasno@gmail.com
} 


\section{Research Method}

\subsection{Research procedure}

This research uses a flow reactor in the form of a pipe with a fixed filling. The reactor is filled with $\mathrm{MoO}_{3}$ /zeolite catalyst grains as a catalyst (Fixed Bed Reactor). The flow rate of the reactants into the reactor is expressed with GHSV. The reactants consist of fuel gas as a source of $\mathrm{CH}_{4}$ and pure $\mathrm{O}_{2}$, with a rate ratio of 20: 1. Inlet gas velocity (GHSV) is set between 2500 to 10000 per hour and the reactor operates at atmospheric pressure. Overall research is done in several stages as follows: Preparation of catalyst/buffer, Impregnation of catalyst, Characterization of catalyst, and continued with catalytic oxidation.

\subsection{Experimental Variables}

a. Operating temperature : $300^{\circ} \mathrm{C}, 400{ }^{\circ} \mathrm{C}, 500{ }^{\circ} \mathrm{C}$, $600{ }^{\circ} \mathrm{C}, 650^{\circ} \mathrm{C}$

b. Methane gas flow rate : $1 \mathrm{lt} / \mathrm{mt} ; 1.51 \mathrm{tt} / \mathrm{mt} ; 2$ $1 \mathrm{t} / \mathrm{mt} ; 2.5 \mathrm{lt} / \mathrm{mt} ; 3 \mathrm{lt} / \mathrm{mt}$

\subsection{Drawing Tools}

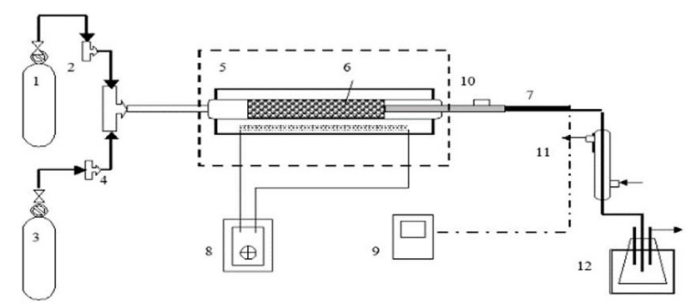

Fig. 1. Equipment Scheme.

Description of Figure 1:

1. Methane gas cylinder

2. Flow meter of methane flow

3. $\mathrm{O}_{2}$ gas

4. Flow meter of flow of $\mathrm{O}_{2}$ gas

5. Furnace reactor

6. Catalyst chamber

7. Thermocouple

8. Thermoset

9. Temperature display

10.Gas sampling

11.Condenser

12.Liquid sample container.

\section{Results and Discussions}

The results of these studies were analyzed using Gas Chromatography. The detector used was a TCD (Thermal Conductivity Detector), while the column type was of a packing column (filling column) PEG, in this column were silica coated with Poly etylen glycol as a liquid. Due to the limitation of existing tools, the products could be analyzed were only formaldehyde, methanol, $\mathrm{H}_{2} \mathrm{O}$ and residual of methane gas. While $\mathrm{CO}$ and $\mathrm{CO}_{2}$ gasses that were supposed to come out were undetected in the chromatogram data. This was probably due to the low resolution of the column packing so that gas $\mathrm{CO}$ and $\mathrm{CO}_{2}$ mixed together with methane gas. The separation resolution in the packing column was not as good as the capillary column.

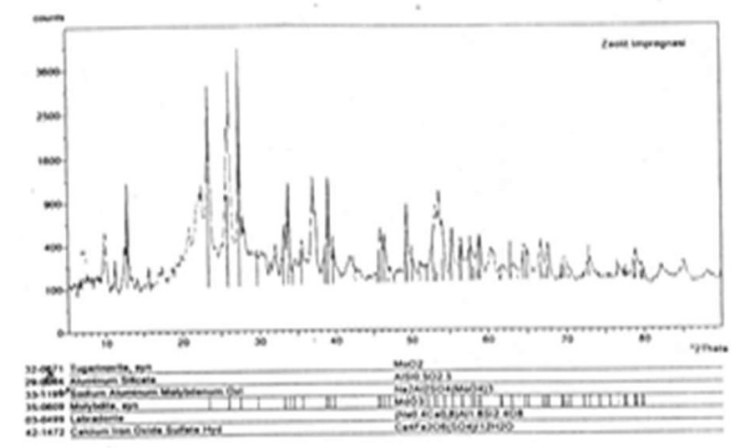

Fig. 2. Impregnation Zeolite

In Figure 2, the diffractogram pattern resulting from the impregnation above can be seen at an angle of 2 theta, namely $23.34^{\circ} ; 25.70^{\circ} ; 25.88^{\circ}$ and $27.34^{\circ}$ These four angles were high peaks and indicate the presence of Mo metal. But the highest at an angle of $27.34^{\circ}$. After the AAS test, the Mo content was found to be $11.43 \%$. According to Wu H.C [5], in the catalytic partial oxidation of methanol to formaldehyde using $\mathrm{MoO}_{3}$ and $\mathrm{Fe}_{2}\left(\mathrm{MoO}_{4}\right)_{3}$ catalysts, these two catalysts have high selectivity. According to Chun J.W [6] on the catalytic oxidation of methane, if the operating pressure is high, the reaction leads to methanol products, whereas if the operating pressure is low, the reaction leads to the formation of formaldehyde. Natural Zeolite from Lampung which has been in BET has surface area of $44.21 \mathrm{~m}^{2} / \mathrm{g}$, while H-zeolite's surface area was 90.17 $\mathrm{m}^{2} / \mathrm{g}$.

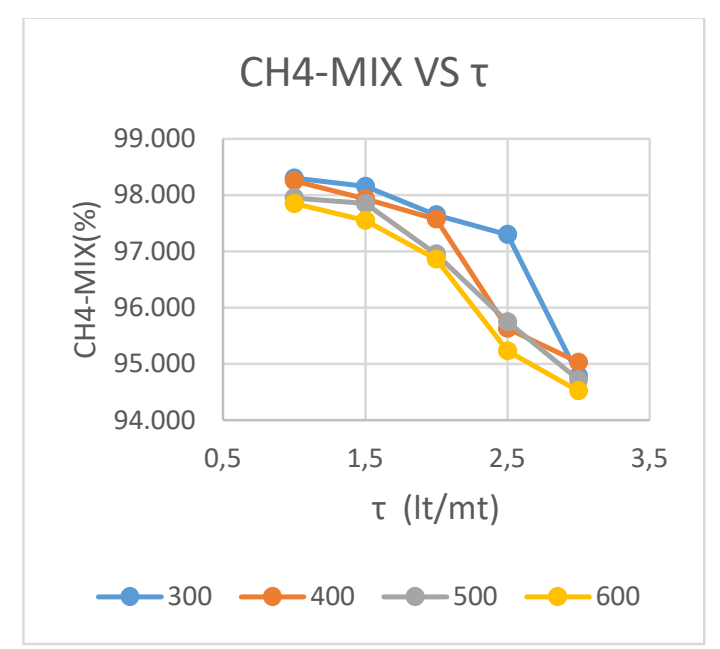

Fig. 3. Relationship between $\mathrm{CH}_{4}$ mixed and $\tau$ at various temperature

Mixed methane $\left(\mathrm{CH}_{4}, \mathrm{CO}, \mathrm{CO}_{2}\right)$. This Mixture is caused by the low resolution of the packing column. So $\mathrm{CO}$ and $\mathrm{CO}_{2}$ Combine with methane gas. The decrease in the concentration of mixed methane is due to the 
length of residence time in the reactor, so the catalytic oxidation rection will run well.

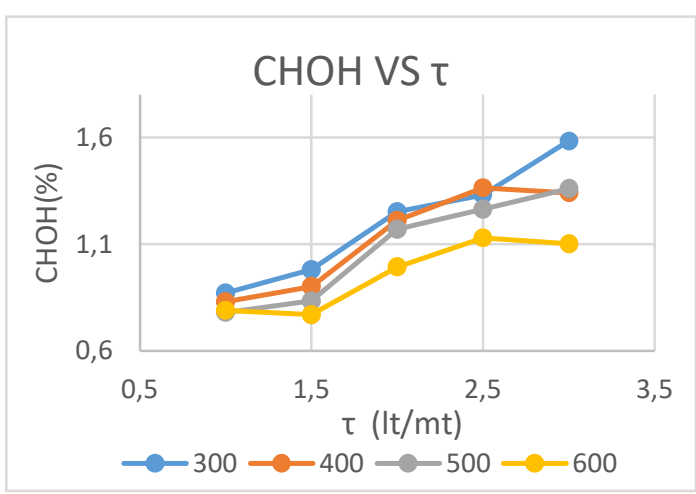

Fig.4. Relationship between $\mathrm{CHOH}$ and $\tau$ at various temperature

As seen in the figure, there is a gradual increase in formaldehyde, then tends to stabilize. this is because the maximum volume of the reactor is no longer capable, so that formaldehyde becomes stable.



Fig.5. Relationship between $\mathrm{H}_{2} \mathrm{O}$ and $\tau$ at various temperature

It can be seen in the figure that $\mathrm{H}_{2} \mathrm{O}$ increased with increasing residence time. Due to the activity of catalyst and also by the formation of $\mathrm{H}_{2} \mathrm{O}$

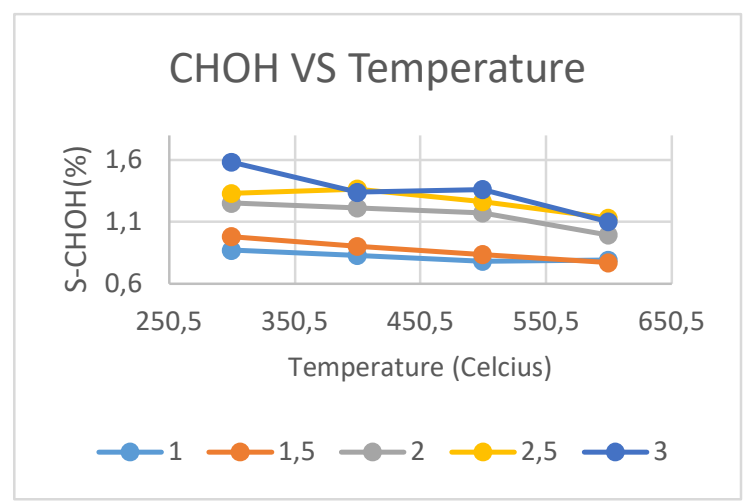

Fig.6. $\mathrm{CHOH}$ selectivity relationship with temperature at various $\tau$

The decrease in selectivity of formaldehyde was due to the formtion of other products during the oxidation reaction, namely $\mathrm{CO}, \mathrm{CO}_{2}, \mathrm{H}_{2} \mathrm{O}$ and metanol. The highest selectivity of formaldehyde occurred at $300{ }^{\circ} \mathrm{C}$ about $97.8 \%$.

\section{Conclusion}

1. From the results of oxidation reaction methane to formaldehyde obtained the highest conversion $\mathrm{CH}_{4}$ of $5.18 \%$ with a volume fraction of formaldehyde out of the reactor $1.46 \%$

2. The catalytic oxidation reaction studied is an order reaction 1 to methane.

\section{References}

[1] Sutarti Mursi, Rachmawati Minta, "Zeolite, literature review ", Pusat Dokumentasi dan Informasi Ilmiah LIPI, (1994).

[2] Nasikin Mohammad., "Aktivation and stability of Lampung natural H-zeolite on ethylene synthesis from etanol", Proseding Seminar Fundamental dan Aplikasi Teknik Kimia FTI ITS, Nopember 1998.

[3] H. Husni., "preliminary study of iron molybdenum oxide catalyst regeneration", Prosiding Seminar Nasional Fundamental dan Aplikasi Teknik Kimia, (2000).

[4] Spencer N.D., Pereira C.J., " Partial Oxidation of Methane to Formaldehide over $\mathrm{MoO}_{3}-\mathrm{SiO}_{2}$ Catalyst: A Kinetik Study", AICHE Journal, Vol. 33, No.11, November (1987).

[5] Wu Hsun Cheng, "Metanol and Formaldehyde Oxidation Study over Molybdenum Oxide", J. of Catalyst 158, (1996).

[6] Chun, Jin Woo and Anthony Rayford G., "Catalytic Oxidation of Methane to Methanol", Ind. Chemical Engineering Journal, Vol. 32, (1993). 